Asian J Agric \& Biol. 2021(4). $\mathrm{AJAB}$ DOI: $10.35495 / a j a b .2021 .01 .057$

Original Article

\title{
Pollination services of Apis cerana and Tetragonula laeviceps (Hymenoptera: Apidae) on strawberry (Fragaria $x$ ananassa)
}

\begin{abstract}
Resi Alpionita ${ }^{1}$, Tri Atmowidi² ${ }^{*}$, Sih Kahono ${ }^{2}$
${ }^{1}$ Department of Biology, Faculty of Mathematics and Natural Sciences, IPB University, Dramaga Campus, Bogor, Indonesia ${ }^{2}$ Laboratory of Entomology, Zoology Division, Research Center for Biology, Indonesian Institute of Sciences (LIPI), Bogor, Indonesia
\end{abstract}

\begin{tabular}{|c|c|}
\hline $\begin{array}{l}\text { Received: } \\
\text { January 29, } 2021\end{array}$ & \\
\hline $\begin{array}{l}\text { Accepted: } \\
\text { May 11, } 2021\end{array}$ & \multirow{3}{*}{$\begin{array}{l}\text { Abstract } \\
\text { Strawberry (Fragaria x ananassa) is a fruit-producing plant with high economic value } \\
\text { and essential horticultural commodities in Indonesia. Although strawberry plants have } \\
\text { hermaphrodite flowers, this plant requires pollinating insects because the mature male } \\
\text { and female organs are not often mature at the same time. Honey bees and stingless bees } \\
\text { were reported as effective pollination agents of various plants. This study aims to } \\
\text { measure the pollination services of Apis cerana and Tetragonula laeviceps on } \\
\text { strawberry plants. Visiting activity of } A \text {. cerana and T. laeviceps were observed by } \\
\text { focal sampling method from } 8 \text { am to } 4 \mathrm{pm} \text {. The pollen load on insects were measured } \\
\text { by using the acetolysis method. The results showed the highest duration visits of } A \text {. } \\
\text { cerana ( } 12.64 \pm 0.47 \text { seconds/flower) and the number of flowers visited ( } 12.80 \pm 0.65 \\
\text { flowers/three minutes) occurred at } 8 \text { to } 9 \text { am. Meanwhile, in } T \text {. laeviceps, the highest } \\
\text { duration visits ( } 89.15 \pm 9.03 \text { seconds/number) and the number of flowers visited } \\
\text { ( } 2.18 \pm 0.22 \text { flowers/three minutes) occurred at } 9 \text { to } 10 \text { am. The number of pollens } \\
\text { carried by A. cerana and T. laeviceps were } 303275 \text { and } 86281 \text { pollen grains, } \\
\text { respectively. Manual and bee pollinations increased the number of fruits formation, } \\
\text { fruit size and weight, and vitamin C content compared with control plants. }\end{array}$} \\
\hline $\begin{array}{l}\text { Online First: } \\
\text { June 08, } 2021\end{array}$ & \\
\hline $\begin{array}{l}\text { Published: } \\
\text { September } 21,2021\end{array}$ & \\
\hline & Keywords: Pollination services, Apis cerana, Tetragonula laeviceps, Strawberry \\
\hline & How to cite this: \\
\hline & $\begin{array}{l}\text { Alpionita R, Atmowidi } \mathrm{T} \text { and Kahono S, 2021. Pollination services of Apis cerana and } \\
\text { Tetragonula laeviceps (Hymenoptera: Apidae) on strawberry (Fragaria x ananassa). }\end{array}$ \\
\hline $\begin{array}{l}\text { *Corresponding author email: } \\
\text { atmowidi@ apps.ipb.ac.id }\end{array}$ & 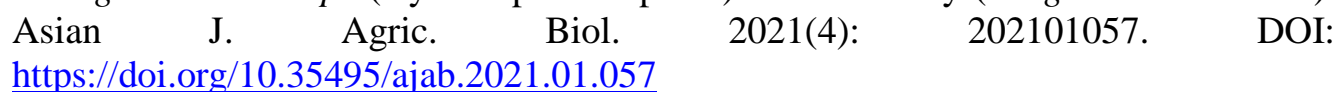 \\
\hline
\end{tabular}

This is an Open Access article distributed under the terms of the Creative Commons Attribution 3.0 License. (https://creativecommons.org/licenses/by/3.0), which permits unrestricted use, distribution, and reproduction in any medium, provided the original work is properly cited.

\section{Introduction}

Insects provide services to natural and artificial ecosystems (Winfree et al., 2008). One of the important services of insects for human life is pollination. About $35 \%$ of food crops in the world need insects to ensure the success of pollination (Widhiono and Sudiana, 2016). Insect pollination provides a significant contribution to agricultural production (Atmowidi et al., 2007; Rianti et al., 2010; Garibaldi et al., 2014). In tomato, pollination by insects increased by $189 \%$ the number of seeds per fruit and $355 \%$ the weight of seeds per fruit (Indraswari et al., 2016). Bees are the most effective pollinator (Pires et al., 2014).

Bees (honey bees and stingless bees) play an important role in pollination process and fruit production (Rader et al., 2015). Apis cerana was reported as an effective 
pollinator on strawberry (MacInnis and Forrest, 2019), apple (Verma and Dulta, 2015), melon (Revanasidda and Belavadi, 2019), and cauliflower and cabbage (Verma and Partap, 2015). This species has a body length of 10-11 mm (Michener, 2000) and active foraging with a distance of 2-3 km (Amano et al., 2000). Stingless bees have high-frequency visits to flowers (Ruslan et al., 2015) and have a prospect as a crop pollinators because they are small, do not sting, have high adaptability to environmental stress, and are easy to handle (Jalil and Shuib, 2014). Previously was reported that Heterotrigona itama increased agricultural crop production, such as watermelon (Azmi et al., 2018) and chayote (A'yunin et al., 2019), while Melipona fasciculata increased eggplant production (Nunes et al., 2013). Pollination by Tetragonula laeviceps was reported to increase seed production, the number of pods, and seed germination of kale (Wulandari et al., 2017), and strawberries (Widhiono et al., 2012; Roselino et al., 2009).

Strawberries have hermaphrodite flowers, which are male and female reproductive organs found in one flower. Although strawberry have hermaphrodite flowers, female organs mature first compared to the male organ (Roselino et al., 2009) and need pollinating insects. Pollination by insects increased the number of fruits, fruit quality, and economic value of strawberries (Klatt et al., 2013). Herrmann et al. (2018) also reported bees were effective pollinators on strawberries and generally increased yields and quality of fruits. The current study aims to measure the pollination services of $A$. cerana and $T$. laeviceps on strawberries by observing visiting activity and measuring fruit production, i.e., the number of perfect fruits and abnormal fruits, fruits size, and sugar and vitamin $\mathrm{C}$ contents.

\section{Material and Methods}

\section{Preparation of strawberry plants and flowers observations}

The Variety of strawberry used in this study was sweet charlie owned by farmers at Sembalun Lawang, West Nusa Tenggara, Indonesia. Strawberries were planted in the soil media with the distance between plants was $50 \mathrm{~cm}$. The plants were fertilized once a month using NPK fertilizer fertilizer (16:16:16) and weed control was done manually once a month. Pest and disease controls were carried out by spraying insecticides, i.e., abamectin and cypermethrin, while fungi disease was controlled by difenoconazole fungicide every two weeks. Strawberry flower properties were observed, such as morphology, colour, the number of sepals and petals, number of stamens and nectary position, and flower bloom time.

\section{The use of A. cerana and T. laeviceps as strawberry pollination}

Strawberry plants used in this study were divided into four treatments, i.e., (a) 50 plants were caged by screen without bee colonies as a control, (b) 50 plants were caged by screen for hand pollination with pollen from a different plant, (c) 50 plants were caged by the screen and added by one colony of T. laeviceps, and (d) 50 open plants added by one colony of $A$. cerana. The size of each cage was $1.50 \mathrm{~m}$ high, $4 \mathrm{~m}$ in length, and $2 \mathrm{~m}$ in width. No replication of each treatment was conducted.

\section{Observation of A. cerana and T. laeviceps visiting activity}

Visiting activity of A. cerana were observed in open plants, while $T$. laeviceps was observed in caged plants using the focal sampling method (Martin and Bateson, 1993). Visiting activities observed were visit duration in a flower (flower handling time), visit duration in a plant (plant handling time), and the number of flowers visited per three minutes (foraging rate) (Dafni, 1992). During observation of bees visiting activities, environmental parameters were measured, i.e., relative humidity, air temperature, light intensity, and wind speed in every hour, starting at 8 am to 4 pm for 20 days.

\section{Pollen load measurements}

Pollen load on A. cerana and T. laeviceps were measured by the acetolysis method (Dafni, 1992). Pollens were collected from A. cerana and T. laeviceps that returned to the hive. One individual of bee was captured and put in a microtube containing $70 \%$ ethanol. Then, the microtube was rotated for 24 hours and then centrifuged at $3500 \mathrm{rpm}$ for 5 minutes. Then, bees were removed from the microtube and centrifuged at $2000 \mathrm{rpm}$ for 3 minutes and the supernatant was removed. The precipitate pollens was added by $1 \mathrm{~mL}$ of solution acetolysis (acetic anhydride and sulfuric acid, 9:1). Samples were heated in a water bath at $80^{\circ} \mathrm{C}$ for 5 minutes and centrifuged at $2000 \mathrm{rpm}$ for 10 minutes. One $\mathrm{mL}$ of distilled water was added to rinse the pollens until the solution was clear. As much as 0.1 $\mathrm{mL}$ of a solution containing pollen was dropped on the hemocytometer. Pollens found in four quadrants of the 
hemocytometer were counted under a light microscope. Measurement of pollen load on each species of bee was conducted as much as 20 times. The number of pollen in one individual bee was calculated by the following formula.

$$
\frac{\mathrm{V}_{1}}{\mathrm{~N}_{1}}=\frac{\mathrm{V}_{2}}{\mathrm{~N}_{2}}
$$

Where $\mathrm{V} 1=$ volume of four quadrants, $\mathrm{V} 2=$ total volume of solution, $\mathrm{N} 1=$ number of pollen counted, and $\mathrm{N} 2=$ total of pollen load

\section{Measurement of fruit formation}

Measurements of fruit formation were carried out on 25 plants that were randomly selected in each treatment. The fruits formation measured were the number of fruits per plant, the number of perfect and abnormal fruits, the length, thickness, and the weight of fruits, the number of seeds per fruit, and the sugar content. The fruits vitamin $\mathrm{C}$ content was also measured by the HPLC method (Seal and Chaudhuri, 2017) in the Analytical Laboratory of the Department of Chemistry, Mataram University, Indonesia.

\section{Statistical analysis}

The relationship between environmental parameters and bees visiting activity was analysed using Pearson correlation in Paleontological Statistics (PAST) 3.20 software. Fruits formation production among treatments were analysed using One-way ANOVA and compared the means using the Tukey test (Hammer et al., 2001).

\section{Results and Discussion}

\section{Flowers morphology}

Strawberry has hermaphrodite flowers that the stamens and ;/" pistil are in a flower. The flower is white and has a cluster-like shape. Flower diameter ranges from 2-3.5 cm, 6-7 white petals with 10-14 green sepals. There are 25-40 stamens attached to the base of the receptacle. The nectaries are situated at the bottom of the stamens and close to the ovary. The blossoms bloom is in the morning (about $6 \mathrm{am}$ ) and flowers do not close until the pistil turns to brown.

\section{Visiting activities of $A$. cerana and $T$. laeviceps}

Results showed that the foraging activity of bees started in the morning until late afternoon. The longest visit duration in one flower of $A$. cerana (12.64 \pm 0.47 seconds/flower) occurred at 8 to 9 am and the shortest $(8.36 \pm 0.48$ seconds/flower) occurred at 1 to $2 \mathrm{pm}$.
While in T. laeviceps, the longest visit duration $(89.15 \pm 9.03$ seconds/flower) occurred at 9 to $10 \mathrm{am}$ and the shortest (33.52 \pm 2.74 seconds/flower) occurred at 1 to $2 \mathrm{pm}$ (Fig. 1). The longest visit duration of $A$. cerana was $18.02 \pm 1.04$ seconds/plant and the shortest was $11.76 \pm 0.57$ seconds/plant. In $T$. laeviceps, the longest visit duration was $99.68 \pm 7.12$ seconds/plant and the shortest was $40.43 \pm 4.55$ seconds/plant (Fig. 2). The results of the current study were similar to Cholis et al. (2020) that peak of $A$. cerana and T. laeviceps visiting activity on pummelo flowers occurred at $8 \mathrm{am}$. During the day (at $1 \mathrm{pm}$ ) this activity decreased and increased again at $4 \mathrm{pm}$. Atmowidi et al. (2018) also reported that the highest activity of $H$. itama occurred at 9-10 am and decreased at 1-2 pm. Visiting activity of bees related to pollen availability. In the morning, the availability of pollens was high and reduced during the day (Tschoeke et al., 2015). The visiting activity of bees on flowers also related to flower colour, availability of nectar and pollen, and the suitability of flower and bee characters (Rianti et al., 2010). Generally, the volume of nectar is high in the morning and decreases in the afternoon that affected visiting duration of insects (Dudareva and Pichersky, 2006).

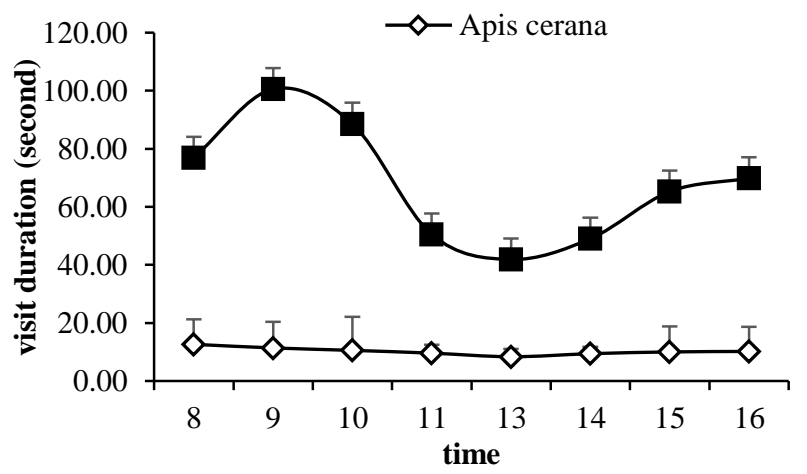

Figure-1. Visit duration in a flower of A. cerana and $T$. laeviceps based on the time of observation. Standard deviation was shown in the graph.

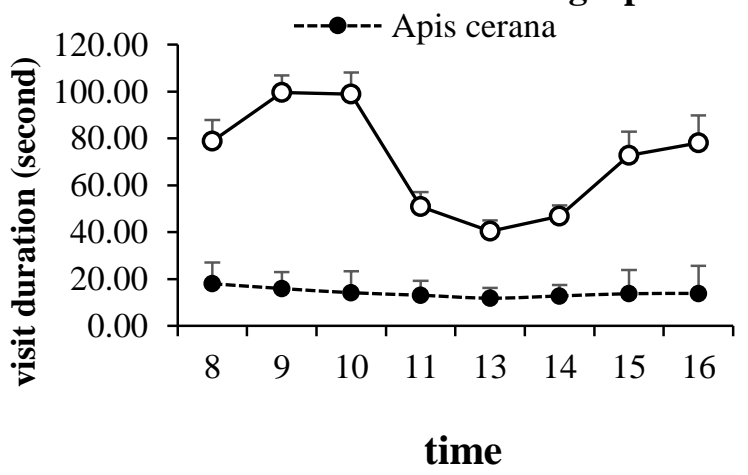

Figure-2. Visit duration in one plant of $A$. cerana and $T$. laeviceps based on the time of observation. 
Standard deviation was shown in the graph.

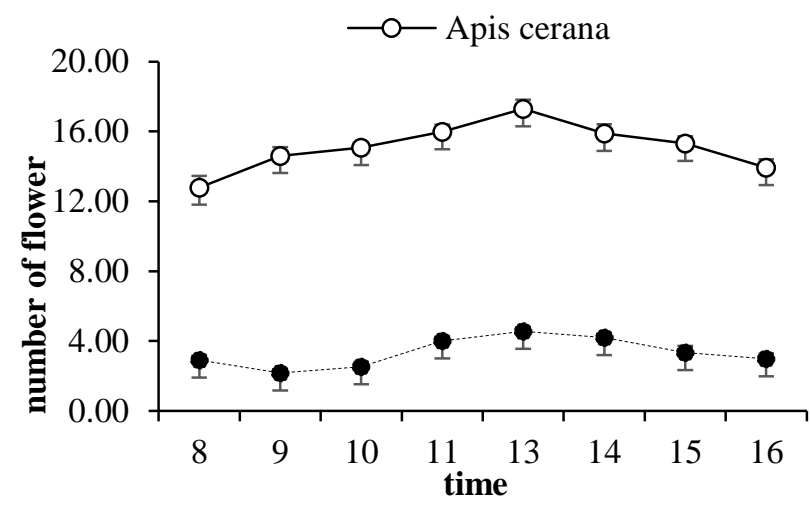

Figure-3. The number of flowers visited per three minutes by $A$. cerana and $T$. laeviceps based on the time of observation. The standard deviation was shown in the graph.

Visiting activity of $A$. cerana and $T$. laeviceps during foraging varied. The number of flowers visited by $A$. cerana at 8-9 am was lower (12.80 \pm 0.65 flowers $/ 3$ minutes) than the day at $11 \mathrm{am}-1 \mathrm{pm}(17.30 \pm 0.52$ flowers/3 minutes). Moreover, T. leaviceps visited $2.91 \pm 0.26$ flowers/3 minutes at $8-9$ am and at noon the species visited $4.55 \pm 0.24$ flowers/3 minutes (Fig. 3 ). Differences in behaviour and visit duration of $A$. cerana and $T$. laeviceps foraging activity possibly related to the body size. Apis cerana has a larger body size than $T$. laeviceps. These results supported Oronje et al. (2012) that larger bees visited more flowers with shorter visits in one flower. Masyitah et al. (2019) also reported bees (A. cerana and Lasioglossum sp.) visit flowers in shorter time (0.25-0.79 minutes/flower) than flies, Episyrphus belteatus and Melanostoma sp. (8-10 minutes/flower). The difference in the visit duration per flower among bee species affects the rate of visits, including the number of flowers visited per time unit. The behaviour of insect pollinators during visits the flowers was also related to environmental factors, flowers shape and colour, as well as the sugar content of nectar (Alao et al., 2016)

Visiting activity of $A$. cerana and $T$. laevicep related to environmental parameters

During measuring the activity of $A$. cerana, the highest temperature and light intensity $\left(35.3{ }^{\circ} \mathrm{C}\right.$ and 18662 lux, respectively) occurred at $1-2 \mathrm{pm}$, while highest air relative humidity $(67.8 \%)$ occurred at $4-5 \mathrm{pm}$ and wind speed occurred at $3-5 \mathrm{pm}(1.11 \mathrm{~m} / \mathrm{s})$. Meanwhile, during measuring activity of T. laeviceps, the highest temperature and light intensity occurred at 1-2 pm (34.7 ${ }^{\circ} \mathrm{C}$ and 18249 lux, respectively) and highest relative humidity $(70.1 \%)$ occurred at 8-9 pm (Table 1). High relative humidity affected sugar concentration in the nectar secreted by flowers and wet pollen make it difficult for bees to pick up a large number of pollens (Ruslan et al., 2015).

Table-1. The average of environmental parameters measured during the observation of $A$. cerana and T. laeviceps

\begin{tabular}{|c|c|c|c|c|c|c|c|}
\hline & \multicolumn{4}{|c|}{ A.cerana } & \multicolumn{3}{c|}{ T. laeviceps } \\
\hline Time & $\begin{array}{c}\text { Temperat } \\
\text { ure }\left({ }^{\circ} \mathbf{C}\right)\end{array}$ & $\begin{array}{c}\text { Humidi } \\
\text { ty (\%) }\end{array}$ & $\begin{array}{c}\text { Light } \\
\text { intensi } \\
\text { ty } \\
(\mathbf{l u x})\end{array}$ & $\begin{array}{c}\text { Wind } \\
\text { speed } \\
(\mathbf{m} / \mathbf{s})\end{array}$ & $\begin{array}{c}\text { Temperat } \\
\text { ure }\left({ }^{\circ} \mathbf{C}\right)\end{array}$ & $\begin{array}{c}\text { Humidi } \\
\text { ty (\%) }\end{array}$ & $\begin{array}{c}\text { Light } \\
\text { intensi } \\
\text { ty } \\
(\mathbf{l u x})\end{array}$ \\
\hline $8-9$ & 23.1 & 63.1 & 8164 & 0.0 & 20.4 & 70.1 & 4555 \\
\hline $9-10$ & 26.5 & 59.8 & 10423 & 0.0 & 23.2 & 63.7 & 7087 \\
\hline $10-11$ & 29.1 & 55.6 & 13174 & 0.18 & 26 & 58.4 & 11014 \\
\hline $11-12$ & 32.2 & 50.3 & 16284 & 0.43 & 30.4 & 51.8 & 15768 \\
\hline $13-$ & 35.3 & 41.5 & 18662 & 1.11 & 34.7 & 46 & 18249 \\
\hline 14. & 32.0 & 50.6 & 16005 & 0.52 & 30.5 & 52.6 & 15358 \\
\hline $14-15$ & 27.3 & 56.2 & 15050 & 0.2 & 26.9 & 60.2 & 10429 \\
\hline $15-16$ & 24.2 & 67.8 & 7181 & 0.0 & 23.6 & 65.2 & 5618 \\
\hline $16-17$ & & & & & & & \\
\hline
\end{tabular}

Pearson correlation analysis showed that visiting activity of $A$. cerana had a positive correlation with air temperature $(\mathrm{r}=0.96 ; \mathrm{p}=0.00)$, light intensity $(\mathrm{r}=0.94$; $\mathrm{p}=0.00)$, and wind speed $(\mathrm{r}=0.89 ; \mathrm{p}=0.00)$, and negatively correlated with humidity $(\mathrm{r}=-0.92 ; \mathrm{p}=0.00)$. While in T. laeviceps, visiting activity had a positive correlation with air temperature $(r=0.86 ; p=0.01)$ and light intensity $(\mathrm{r}=0.83 ; \mathrm{p}=0.01)$ (Table 2$)$.

Table-2. Pearson correlation between visiting activities of $A$. cerana and $T$. laeviceps and environmental parameters.

\begin{tabular}{|c|c|c|c|c|}
\hline \multirow{2}{*}{$\begin{array}{c}\text { Environment } \\
\text { parameters }\end{array}$} & \multicolumn{2}{|c|}{ A. cerana } & \multicolumn{2}{c|}{ T. laeviceps } \\
\cline { 2 - 5 } & $\mathrm{r}$ & $\mathrm{p}$ & $\mathrm{r}$ & $\mathrm{p}$ \\
\hline $\begin{array}{c}\text { Temperature } \\
\left({ }^{\circ} \mathrm{C}\right)\end{array}$ & 0.96 & 0.00 & 0.86 & 0.01 \\
\hline Humidity (\%) & -0.92 & 0.00 & -0.81 & 0.02 \\
\hline $\begin{array}{c}\text { Light intensity } \\
(\text { lux })\end{array}$ & 0.94 & 0.00 & 0.83 & 0.01 \\
\hline $\begin{array}{c}\text { Wind speed } \\
(\mathrm{m} / \mathrm{s})\end{array}$ & 0.89 & 0.00 & - & - \\
\hline
\end{tabular}


The visiting activity of bees on a strawberry is influenced by temperature, relative humidity, light intensity, and wind speed. Wulandari et al. (2017) reported the optimal temperature $\left(26-34^{\circ} \mathrm{C}\right)$ supported the activity of pollinating insects on kale (Brassica oleraceae). High humidity and lower temperature caused decrease activity of bees on flowers (Ruslan et al., 2015). To maintain body temperature during flight, bees use a thermoregulation mechanism (Tan et al., 2014).

\section{Pollen load}

Pollen of strawberry is a tricolpate with prolate shape in equatorial view (Fig. 4a) and circular-lobate in polar view (Fig. 4b). Stingless bee is hairy and pollens easily attach to the body when bees visit the flowers. Two species of bees, A. cerana and $T$. laeviceps have corbicula as pollen collector (Rahman et al., 2014).
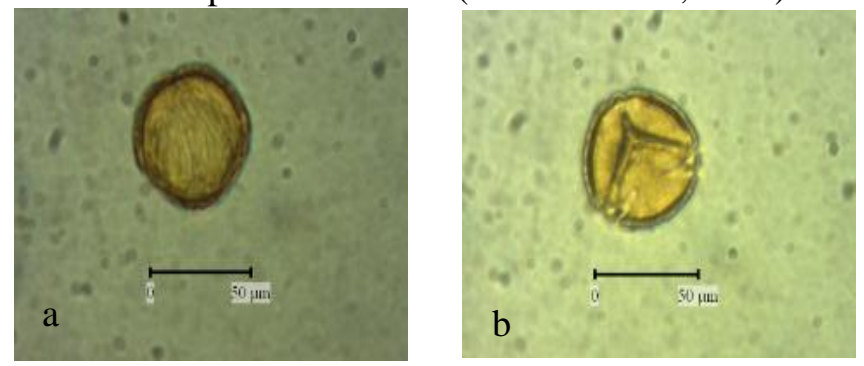

Figure-4. Morphology of strawberry pollen: (a) prolate (equatorial view), (b) circular-lobate (polar view).

Based on the number of pollens attached to the hind legs showed that bee actively visited the flowers. Apis cerana carried more pollens (303275 pollen grains) than T. laeviceps (8628 pollen grains) (Fig. 5 a). Current study showed that the body size effect the pollen carried. Pangestika et al. (2017) stated the higher pollen loads were observed in H. itama (31392 pollen grains) and $T$. laeviceps (8015 pollen grains). In stingless bees, pollens were commonly found in the thorax, tarsus, and corbicula (Chan and Saw, 2011).

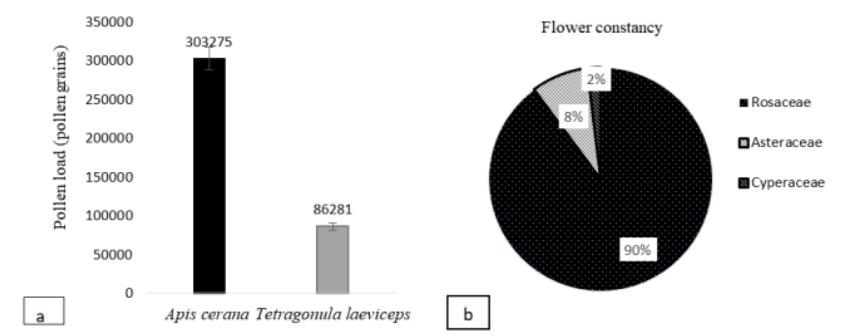

Figure-5. Pollen load on A. cerana and T. laeviceps (a) and type of pollens attached to A. cerana (b).
In open plants, A. cerana prefer to visit strawberry flowers compared to other plants because the location of the bee colony is very close. Khairiah et al. (2012) reported bees tend to visit flowers of the same plant species that are close to their nests. In honey bees, information of food source location is informed to other bees using a round-dance (Schoonhoven et al., 1998). Results showed that the dominant pollen type attached on A. cerana was the pollen of Rosaceae (90\%) followed by Asteraceae (8\%), and Cyperaceae (2\%) (Fig. 5 b). The percentage of flowers visited by bees depends on the plants around the nest and the availability of food and pollinators prefer to choose flowers that are easily accessible (Widhiono and Sudiana, 2016)

\section{Fruit formation}

Results showed that $A$. cerana pollination in strawberries yielded $4.76 \pm 1.05$ fruits/plant with a percentage of perfect fruit was $77.31 \%$ and abnormal fruit was $22.69 \%$. While, pollination by $T$. laeviceps yielded $4.24 \pm 0.92$ fruits/plant with a percentage of perfect fruit was $71.70 \%$ and abnormal fruit was $28.30 \%$. Human-assisted pollination using pollen from different plants yielded 5.04 \pm 1.04 fruits/plant with a percentage of perfect fruits was $76.98 \%$. In control plants, the low yielded low number of fruits $(2.08 \pm 0.70$ fruits/plant), low perfect fruits $(40.38 \%)$, and high abnormal fruits $(59.62 \%)$ (Table 3$)$.

Pollinating insects affected on the strawberry fruits. The Current study supported Adhikari and Miyanaga (2016) that reported pollination by A. plumipes increased strawberry fruit formation $(59.9 \%)$ than that in control plants (31.0\%). Abrol et al. (2017) also reported a lower percentage of abnormal fruit formation (11.20\%) in plants pollinated by bees compared to control plants $(17.44 \%)$. Hasan et al. (2017) also stated insects affected the cucumber production. Crop yielded also is influenced by genetic and environmental factors, as well as the status of soil nutrients and insect-plant interaction (Susilawati, 2016).

Pollination by $A$. cerana increased strawberries fruit size $(3.90 \pm 0.45 \mathrm{~cm}$ in length, $3.61 \pm 0.36 \mathrm{~cm}$ in thickness, and $18.94 \pm 4.00 \mathrm{~g}$ in weight) and sugar content $(8.07 \%)$. Likewise, pollination by T. laeviceps increased fruit size $(3.57 \pm 0.48 \mathrm{~cm}$ in length, $3.43 \pm 0.40$ $\mathrm{cm}$ in thickness, and $15.11 \pm 5.33 \mathrm{~g}$ in weight). Pollination by insects especially bees produced heavier fruits and contains high nutrients (Neto et al., 2013). Control plants had a smaller fruit size $(2.69 \pm 0.62 \mathrm{~cm}$ in 
length, $2.73 \pm 0.66 \mathrm{~cm}$ in thickness, and $10.27 \pm 2.41 \mathrm{~g}$ in weight). Based on ANOVA analysis, fruit weight of hand pollination, pollination by A. cerana, and pollination by $T$. laeviceps was significantly different with control plants ( $\mathrm{p}<0.001)$. Adhikari and Miyanaga (2016) also stated a higher fruit set of strawberry in hand- and A. plumipes pollination (95\%) compared to control plants $(40 \%)$. This may be related to visiting activities of $A$. cerana and $T$. laeviceps from morning to evening and allows cross-pollination occurred. Klatt et al. (2013) reported that increasing fruits quantity and size in strawberry pollination by bees. Absence of insects in control plants caused cross-pollination does not work well and transfer of pollen to the stigma does not occur.

Table-3. Fruits formation of strawberry pollinated by $A$. cerana, $T$. laeviceps, and manual pollination.

\begin{tabular}{|c|c|c|c|c|}
\hline \multirow{2}{*}{$\begin{array}{l}\text { Yield } \\
\text { Components }\end{array}$} & \multicolumn{4}{|c|}{ Fruits Formation (Average \pm st. deviation)* } \\
\hline & $\begin{array}{c}\text { Hand } \\
\text { pollination }\end{array}$ & A. cerana & T. laeviceps & $\begin{array}{l}\text { Control } \\
\text { plants }\end{array}$ \\
\hline \multirow{2}{*}{$\begin{array}{l}\text { Number of } \\
\text { perfect fruits } \\
(\%)\end{array}$} & $5.04 \pm 1.04^{\mathrm{a}}$ & $4.76 \pm 1.05^{\mathrm{ab}}$ & $4.24 \pm 0.92^{\mathrm{b}}$ & $2.08 \pm 0.70^{\mathrm{c}}$ \\
\hline & $76.98^{\mathrm{a}}$ & $77.31^{\mathrm{a}}$ & $71.70^{\mathrm{b}}$ & $40.38^{\mathrm{c}}$ \\
\hline $\begin{array}{l}\text { Number of } \\
\text { abnormal fruits } \\
(\%)\end{array}$ & $23.02^{\mathrm{a}}$ & $22.69^{\mathrm{a}}$ & $28.30^{\mathrm{b}}$ & $59.62^{c}$ \\
\hline $\begin{array}{l}\text { Fruit length } \\
(\mathrm{cm})\end{array}$ & $3.77 \pm 0.44^{\mathrm{a}}$ & $3.90 \pm 0.45^{\mathrm{a}}$ & $3.57 \pm 0.48^{\mathrm{a}}$ & $2.69 \pm 0.62^{\mathrm{b}}$ \\
\hline $\begin{array}{l}\text { Fruit thickness } \\
(\mathrm{cm})\end{array}$ & $3.53 \pm 0.40^{\mathrm{a}}$ & $3.61 \pm 0.36^{\mathrm{a}}$ & $3.43 \pm 0.40^{\mathrm{a}}$ & $2.73 \pm 0.66^{\mathrm{b}}$ \\
\hline Fruit weight $(\mathrm{g})$ & $17.07 \pm 3.08^{\mathrm{ab}}$ & $18.94 \pm 4.00^{\mathrm{a}}$ & $15.11 \pm 5.33^{\mathrm{b}}$ & $10.27 \pm 2.41^{\mathrm{c}}$ \\
\hline $\begin{array}{l}\text { Number of fruit } \\
\text { achenes }\end{array}$ & \begin{tabular}{|c|}
$309.5 \pm 53.39$ \\
ab
\end{tabular} & $344.8 \pm 83.92^{\mathrm{a}}$ & $284.5 \pm 69.60^{\mathrm{ab}}$ & $255.6 \pm 49.5^{\mathrm{b}}$ \\
\hline $\begin{array}{l}\text { Sugar content } \\
\text { (\% Brix) }\end{array}$ & $6.68^{\mathrm{a}}$ & $8.07^{\mathrm{ab}}$ & $7.10^{\mathrm{ab}}$ & $4.48^{\mathrm{c}}$ \\
\hline \multirow{2}{*}{$\begin{array}{l}\text { Vitamin C } \\
\text { content } \\
(\mathrm{g} / 100 \mathrm{~g})\end{array}$} & & & & \\
\hline & - & $60.75^{\mathrm{a}}$ & $50.85^{\mathrm{b}}$ & $38.5^{\mathrm{c}}$ \\
\hline
\end{tabular}

*Values on the same row followed by the same letters do not showed a significant difference (Tukey test $95 \%)$.

The insect pollination of strawberry results reddish and heavier fruits weight and also higher storage resistance compared to non-insect-pollination (Klatt et al., 2013). Successfully pollination trigger hormones in flowers, such as gibberellin, cytokines, auxin, and abscisic acid (Iglesias et al., 2007) to promote fruits growth. Also, fruit yielded by strawberry pollinated by $A$. cerana and $T$. leaviceps had a higher vitamin $\mathrm{C}$ content (60.7\%/100g sample) than control plants $(38.5 \% / 100 \mathrm{~g}$ sample). Pollinators also increased fruits micronutrients, such as vitamins $\mathrm{A}$ and $\mathrm{C}$, calcium, fluoride, and folic acid (Smith at al., 2015). Therefore, bees can be used as an alternative pollinator for strawberry plants (Adhikari and Miyanaga, 2016).

\section{Conclusion}

Apis cerana and T. laeviceps contributed to increase of fruit production of strawberry plants. The high visiting activity of $A$. cerana and $T$. laeviceps on strawberry flowers occurred in the morning and decreased during the day. Visiting activity of bees correlated with environmental factors. The average, A. cerana carried more pollens (303275 pollen grains) than $T$. laeviceps (8628 pollen grains). Pollination by A. cerana and $T$. laeviceps, as well as hand-pollination significantly increased the formation of fruits, i.e., with the number of normal shapes, fruits size and weight, and vitamin C content.

\section{Acknowledgement}

The part of funding of this research was supported by the Decentralization Scheme of Basic Research of Higher University (PDUPT-IPB University), Ministry of Research, Technology and Higher Education, Republic of Indonesia in 2019 by Tri Atmowidi (129/SP2H/PTNBH/DRPM/2018 and 3/E1/KP.PTNBH/2019).

Disclaimer: None.

Conflict of Interest: None.

Source of Funding: None.

\section{References}

Atmowidi T, Prawasti TS and Raffiudin R, 2018. Flight Activities and Pollen Load of Three Species of Stingless Bees (Apidae: Melliponinae). IOP Conf. Series: Earth Environ. Sci. 197: 012025.

Atmowidi T, Buchori D, Manuwoto S, Suryobroto B and Hidayat $P, 2007$. Diversity of pollinator insects in relation to a seed set of mustard (Brassica rapa L: Cruciferae). Hayati J. Biosci. 14: 155-161.

A'yunin Q, Rauf A and Harahap IS, 2019. Foraging Behaviour and Pollination Efficiency of Heterotrigona itama (Cockerell) and Tetragonula laeviceps (Smith) (Hymenoptera: Apidae) on 
Chayote. Indones. J. Agric. Sci. 24(3): 247-257.

Adhikari RD and Miyanaga R, 2016. Utilization of Hairy Footed Flower Bee Anthophora plumipes (Hymenoptera: Apidae) for Pollination of Greenhouse Strawberry. J. Sci. Res. 4: 25-31.

Amano K, Nemoto T and Heard TA, 2000. What are stingless bees, and why and how to use them as crop pollinator? a review. JARQ. 34(3): 183-190.

Azmi WA, Sembok WWZ, Yusuf N, Mohd MF, Hatta, Salleh AF, Hamzah MAH and Raml SN, 2018. Effects of Pollination by the Indo-Malaya Stingless Bee (Hymenoptera: Apidae) on the Quality of Greenhouse Produced Rockmelon. J. Econ. Entomol. 20(10): 1-5.

Abrol DP, Gorka AK, Ansari MJ, Al-Ghamdi A and Al-Kahtani S. 2017. Impact of insect pollinators on yield and fruit quality of strawberry. Saudi J Biol Sci 3(26): 524-530.

Alao FO, Adebayo TA and Olaniran OA, 2016. Population Density of Insect Pests Associated with Watermelon (Citrullus lanatus Thumb) in Southern Guinea Savanna Zone, Ogbomoso. J. Entomol. Zool. Stud. 4(4): 257- 260.

Chan YM and Saw LG, 2011. Notes on the Pollination Ecology of the Palm Genus Johannesteijsmannia (Arecacea). J. Poll. Ecol. 6(15): 108-117.

Cholis MN, Atmowidi T and Kahono S, 2020. The diversity and abundance of visitor insects on pummelo(Citrus maxima (burm) Merr) cv. Nambangan. J. Entomol. Zool. Stud. 8(4): 344351.

Dafni A, 1992. Pollination Ecology: A Practical Approach. Oxford University, Oxford, UK.

Dudareva N and Pichersky E, 2006. Biology of Floral Scent. London (GB): Taylor and Francis

Garibaldi LA, Carvalheiro LG, Leonhardt SD, Aizen MA, Blaauw BR, Isaacs R, Kuhlmann M, Kleijn D, Klein AM, Kremen C, Morandin L, Scheper J and Winfree R, 2014. From research to action: enhancing crop yield through wild pollinators. Front. Ecol. Environ. 12: 439-447.

Hasan PA, Atmowidi T and Kahono S, 2017. Diversity, foraging behaviour, and effectiveness of insect pollinators on cucumber plants (Cucumis sativus Linn.). Indon. J. Entomol. 14(1):1-9.

Herrmann JD, Beye H, Boise CDL and Hartlep H, 2018. Positive effects of the pollinators Osmia cornuta (Megachilidae) and Lucilia sericata (Calliphoridae) on strawberry quality. J. Poll. Eco. 6(15): 108-117.

Hammer O, Harper DAT and Ryan PD, 2001. PAST-
Palaeontological statistics software package for educational and data analysis. Palaeontologia Electronica. 9(1): 9pp.

Iglesias JD, Cercós M, Colmenero-Flores JM, Naranjo MA, Ríos G, Carrera E,Ruiz-Rivero O, Lliso I, Morillon R and Tadeo FR, 2007. Physiology of citrus fruiting. Braz. J. Plant Physiol. 19(4): 333 362.

Indraswari AGM, Atmowidi T and Kahono S, 2016. Diversity, foraging activity, and effectiveness of bee pollinators in tomato plants (Solanum lycopersicum L: Solanaceae). Indon. J. Entomol. 13(1): 21-29.

Jalil AH and Shuib I, 2014. Beescape for Meliponines Conservation of Indo-Malayan Stingless Bees. Patridge, Malaysia.

Khairiah D, Dahelmi and Syamsuardi, 2012. The species of visitor insects of balsam flower (Impatiens balsamina Lin: Balsaminaceae). J. Biol. Andalas Univ. 1(1): 9-14.

Klatt BK, Holzschuh A, Westphal C, Clough Y, Smit I, Pawelzik E and Tscharntke T, 2013. Bee pollination improves crop quality, shelf life and commercial value. Proc. Biol. Sci. 281(1775): 20132440.

Martin P and Bateson P, 1993. Measuring Behavior. Cambridge University Press, Cambridge, UK.

Michener CD, 2000. The Bees of The World. The Johns Hopkins University Press, Baltimore, USA.

MacInnis G and Forrest JRK, 2019 Pollination by wild bees yields larger strawberries than pollination by honey bees. J. Appl. Ecol. 56: 824-832.

Masyitah S, Rauf A, Maryana N and Kahono S, 2019 Pollination services of flower-visiting insects in strawberry fields in Ciwidey, Bandung. Indon. J. Entomol. 16(2): 115-127.

Nunes SP, Hrncir M, Silva CI, Roldão YS and Imperatriz- Fonseca VL, 2013. Stingless bees, Melipona fasciculata, as eficiente pollinators of eggplant (Solanum melongena) in greenhouses. Apidologie. 44(5): 537-546.

Neto CMS, Lima FG, Gonçalves BB, Bergamini LL, Bergamini BAR, Elias MAS and Franceschinelli EV, 2013. Native bees pollinate tomato flowers and increase fruit production. J. Poll. Ecol. 11(6): 41-45.

Oronje ML, Hagen M, Gikungu M, Kasina M and Kraemer M, 2012. Pollinator diversity, behaviour and limitation on yield of karela (Momordica charantia L. Cucurbitaceae) in Western Kenya. Afr. J. Agric. Res. 7(11): 1629-1638. 
Pangestika NW, Atmowidi T and Kahono S, 2017. Pollen Load and Flower Constancy of Three Species of Stingless Bees (Hymenoptera, Apidae, Meliponinae). Trop. Life Sci. Res. 28(2): 179-187.

Pires VC, Silveira FA, Sujii ER, Torezani KRS, Rodrigues WA, Albuquerque FA, Rodrigues SM, Salamao AN and Pires CS, 2014. Importance of bee pollination for cotton production in conventional and organic farms in Brazil. J. Poll. Ecol. 13(16): 151-160.

Rader R, Bartomeus I, Garibaldi LA, Garrat MPD, Howlett BG, Winfree R, Cunningham SA, Mayfield MM, Arthur AD and Georg KSA, 2015. Nonbee insects are important contributors to global crop pollination. PNAS. 113(1): 146-151.

Rahman R, Thangkiew I and Hajong SR, 2014. Hypopharyngeal gland activity in taskspecific workers under brood and broodless conditions in Apis cerana Indica (Fab.). J. Apic. Sci. 58(2): 5970

Revanasidda and Belavadi VV, 2019. Floral biology and pollination in Cucumis melo L. a tropical andromonoecious cucurbit. J. Asia-Pac. Entomol. 22: 215-225.

Rianti P, Suryobroto B and Atmowidi T, 2010. Diversity and effectiveness of insect pollinators of Jatropha curcas L. (Euphorbiaceae). Hayati J. Biosci. 17(1): 38-42.

Roselino AC, Santos SB, Hrneir M and Bego LR, 2009. Differences between the quality of strawberries (Fragaria $\mathrm{x}$ ananassa) pollinated by the stingless bees Scaptotrigona aff. depilis and Nannotrigona testaceicornis. Gen. Mol. Res. 8: 539-545.

Ruslan W, Afriani, Miswan, Elijonnahdi, Nurdiyah, Sataral M, Fitrallisan and Fahri, 2015. Visited Frequency of Apis cerana and Trigona sp. as Bee Pollinators at Brassica rapa Plant. J. Nat. Sci. 4(1): 65-72.

Schoonhoven S, Jerry LMT and Voon Loon JJA, 1998. Insect-Plant Biology. From Physiology to Evolution. 1st Ed. Cambridge: Chapman and Hall.

Smith MR, Singh GM, Mozaffarian D and Myers SS, 2015. Effects of decreases of animal pollinators on human nutrition and global health: A modelling analysis. Lancet. 386: 1964-1972.

Seal T and Chaudhuri K, 2017. High Performance Liquid Chromatography Method for the Estimation of Water Soluble Vitamin in Five Wild Edible Fruits Consumed by the Tribal People of NorthEastern Region in India. Int. J. Curr. Microbiol.
6(10): 2900-2913.

Susilawati, 2016. Diversity and the Abundance level of Cucumber's Flower visiting Insects in Different Landscape Structure. MS Theses, Bogor Agricultural University, Bogor, Indonesia.

Tan K, Latty T, Hu Z, Wang Z, Yang S, Chen W and Oldroyd BP, 2014. Preferences and tradeoffs in nectar temperature and nectar concentration in the Asian hive bee Apis cerana. Behav. Ecol. Sociobiol. 68:13-20.

Tschoeke PH, Eugênio E, Oliveirab, Mateus SD, Marcela CAC, Silveira T and Gil RS, 2015. Diversity and flower-visiting rates of bee species as potentialpollinators of melon (Cucumis melo L.) in the Brazilian Cerrado. Scientia Hort. 186 (15): 207-216.

Verma LR and Dulta PC, 2015. Foraging Behaviour of Apis Cerana Indica and Apis Mellifera in Pollinating Apple Flowers. J. Apic. Res. 25: 4 197201.

Verma LR and Partap U, 2015. Foraging behaviour of Apis cerana on cauliflower and cabbage and its impact on seed production. J. Apic. Res. 33 (4): 231-236.

Winfree, Williams NM, Caines H, Ascher JS and Kremen C, 2008. Wild bee pollinators provide the majority of crop visitation across land-use gradients in New Jersey. J. App. Ecol. 45: 793-802.

Wulandari AP, Atmowidi T and Kahono S, 2017. Peranan lebah Trigona laeviceps Smith (Hymenoptera: Apidae) dalam produksi biji Kailan (Brassica oleracea var. Alboglabra). J. Agron. Indon. 45(2): 197-204.

Widhiono I, Sudiana E and Sucianto ET, 2012. Local bee potential in increasing strawberry production (Fragaria x ananassa). J. Innov. 6(2): 163-168.

Widhiono I and Sudiana E, 2016. Impact of Distance from the Forest Edge on The Wild Bee Diversity on the Northern Slope of Mount Slamet. Biosaintifika: J. Biol. Biol. Edu. 8(2): 148-154.

\section{Contribution of Authors}

Alpionita R: Designed research methodology, collected and analysed data and wrote manuscript Atmowidi $\mathrm{T} \&$ Kahono S: Helped in literature review, editing and proof reading of manuscript. 